\title{
Mysterious Bodies: Aristotelian Animal Generation and the Early Christian Doctrine of Bodily Resurrection
}

\author{
Anne Siebels Peterson \\ Brandon R. Peterson
}

How does a living body come to be? What happens when it passes away? Questions like these captivated both Aristotle and St. Paul, despite their significantly different times and cultures. While it does not make any claim that Paul explicitly relied on Aristotle, this article does argue that each of them faced down parallel dilemmas and responded with the same conceptual move. Writing on animal generation, Aristotle rejected theories which overemphasize continuity through the developmental process or so stress the intelligibility of discrete stages that the process itself disintegrates without coherence. Likewise, Paul, writing on the plausibility of bodily resurrection, exhorts the Christian community in Corinth to reject overly continuous caricatures of resurrection while also urging them not to abandon hope for the bodies of those who have died - "what you sow," he tells them, "come[s] to life." Both Paul and Aristotle point their readers toward accounts of bodily development which refuse to collapse into either identity with the past or discontinuity between past and future - Paul and Aristotle insist on both. Such insistence is plausible on each of their accounts because they advance a shared conceptual shift away from prioritizing the temporal order of bodily change and toward a teleological order which privileges a greater whole.

Listen, I will tell you a mystery! We will not all die, but we will all be changed, in a moment, in the twinkling of an eye, at the last trumpet. (1 Corinthians 16.51-52) ${ }^{1}$

Every realm of nature is marvellous: and as Heraclitus, when the strangers who came to visit him found him warming himself at the furnace in the kitchen and hesitated to go in, is reported to have bidden them not to be afraid to enter, as even in that kitchen divinities were present, so we should venture on the study of every kind of animal. (Aristotle, Parts of Animals 1.5, 17-22) $)^{2}$

\footnotetext{
${ }^{1}$ Quotations from the Bible are taken from the New Revised Standard Version (NRSV) translation. Michael D. Coogan (ed.), The New Oxford Annotated Bible: New Revised Standard Version with the Apocrypha, $4^{\text {th }}$ edition (New York: Oxford University Press, 2010).

${ }^{2}$ All citations of Aristotle are taken from Jonathan Barnes, The Complete Works of Aristotle, 2 vols. (Princeton, NJ: Princeton University Press, 1984).
} 


\section{Introduction}

Aristotle's biological writings highlight his commitment to investigating the natural world, in particular the generation and life of animals of every sort. In Parts of Animals (PA)1.5 he compares the study of natural things with the study of eternal things. Despite the humbler status of natural things, the same marvelousness and beauty is to be found in both realms alike, just as Heraclitus reportedly affirms to his visitors that "divinities" are present even in the humbleness of his kitchen. Aristotle continues:

so we should venture on the study of every kind of animal without distaste; for each and all will reveal to us something natural and something beautiful. Absence of haphazard and conduciveness of everything to an end are to be found in nature's works in the highest degree, and the end for which those works are put together and produced is a form of the beautiful. (645a21-25)

These words are contentious ones. Whereas Plato locates true beauty only in the form of the beautiful itself, separate from natural things, Aristotle here uses Plato's terminology (to kalon) to describe the beauty found in natural objects. The very beauty that Plato confined to the eternal realm of the forms is extended to all parts of the world, even to the humblest of natural creatures: "we proceed to treat of animals, without omitting, to the best of our ability, any member of the kingdom, however ignoble. For if some have no graces to charm the sense, yet nature, which fashioned them, gives amazing pleasure in their study to all who can trace links of causation, and are inclined to philosophy" (645a5-10). The beauty and mystery found in the eternal realm is not confined to that realm; it spills over into the natural realm as well.

Aristotle's worldview differed deeply and irreconcilably from the later worldview of early Christians such as the apostle Paul. Despite these differences, we will argue that a mystery with the same philosophical structure can be identified in both the Aristotelian and the Pauline contexts, and moreover that Aristotle and Paul address this mystery in the same way. The mystery takes the form of an apparent dilemma. Before setting out this dilemma, it is important to emphasize that we are not making a historical argument that Paul explicitly or consciously used Aristotelian philosophy in this case. Rather, our argument is purely philosophical - the same mystery and the same way of addressing it arise in both Paul and Aristotle, however different the original motivations of each may be.

In 1 Corinthians 15, Paul, like Aristotle, is intent to emphasize a strange and even, to his audience, shocking point of connection between the natural and the eternal realms. But he describes a mystery that bridges the eternal and the natural to an extent that Aristotle never 
would have considered: the resurrection of the earthly body as an incorruptible, "spiritual" body. "What is sown is perishable, what is raised is imperishable. It is sown in dishonor, it is raised in glory. It is sown in weakness, it is raised in power. It is sown a physical body, it is raised a spiritual body" (1 Cor 15.42-44). Paul's understanding of the relationship between the earthly and the resurrected body implies, at least on the prominent Irenaean reading, both continuity and discontinuity: the resurrected body is numerically the same body as the earthly body, yet it is deeply transformed.

Despite the fact that Aristotle never would have countenanced the possibility of bodily resurrection, we will argue that he identifies an analogously mysterious phenomenon purely within the natural world: the generation of animals. In animal generation, the animal develops from early embryonic to more complex stages. Aristotle too is committed to continuity between the embryo and the animal body as it continues to develop, as well as to the disparities between different stages of animal development. He wants to secure the idea that it is one body through the whole developmental process, even though its specific features do change drastically as new parts develop.

How can both of these commitments be secured? What background framework for understanding this phenomenon could support the conclusion that there is one body all along, without downplaying the genuine discontinuities between its different stages? After explaining the shared challenge in each of these cases - a dilemma between the two horns of continuity and discontinuity that characterize the process of growth undergone by the body, in animal generation for Aristotle and in the process of the resurrection for Paul-we will argue that Aristotle and Paul go on to address it in the same way: by making a distinction between the temporal order that we are used to observing and a non-temporal, yet more fundamental and important, order. They go on to argue that within the context of this more fundamental order, the disparity or discontinuity at hand is not opposed to or inconsistent with the continuity at hand. Rather than defusing the mystery by choosing one horn of the dilemma over the other, Aristotle and Paul alike embrace the mystery by turning to a new order in which the two horns are reconciled.

\section{Paul and the Greeks: The Puzzle of Resurrection}

Although Jesus is obviously at the center of Christianity's message, there is no person of greater importance to its successful spread than Paul (d. 60s C.E.). As Paul attests in his 
letters, which make up the earliest stratus of the Christian New Testament, he was "a member of the people of Israel, of the tribe of Benjamin, a Hebrew born of Hebrews; as to the law, a Pharisee; as to zeal, a persecutor of the church" (Phil 3.5-6; cf. Gal 1.13). However, he underwent a life-changing transformation when "God, who $<\ldots>$ called me through his grace, was pleased to reveal his Son to me, so that I might proclaim him among the Gentiles" (Gal 1.15-16). Paul's encounter with the risen Jesus spurred intensive missionary activity as he traveled around Asia minor, Greece, and eventually to Rome, preaching what he called the Gospel (euangelion, literally the "good message") and establishing small Christian communities. One such community was the church in Corinth, to which he wrote at least two letters.

\section{I.1. Background: Paul and his Interpreters}

Paul's first letter to the Corinthians is wide-ranging and addresses a number of controversies that have arisen in the community since his departure: factions and rivalries, questions about rituals and food, and the doctrine of the resurrection. In response, Paul introduces now famous imagery, explaining to the divided Corinthians that they are all united as members of a single body, that of Christ. On the topic of resurrection, he appeals to the image of a seed that enters the ground in one condition and emerges in a wondrously new one. Before exploring this specific analogy in a later section, we must first consider the situation that prompted him to employ it and his broader strategy for responding to that situation.

Paul himself addresses the situation head on, interrogating the community, "how can some of you say there is no resurrection of the dead?" (15.12) The idea of resurrection was a controversial one, even within the Jewish context from which early apostles like Paul received it. The first straightforward reference to the idea in the Hebrew Bible is the apocalyptic Book of Daniel, written in the 160s B.C.E. ${ }^{3}$ And among Jews in the first century C.E., the notion was contentious; the Christian New Testament reports that while Pharisees like Paul accepted the doctrine, the more traditional Sadducees remained skeptical of it. ${ }^{4}$

\footnotetext{
3 "Many of those who sleep in the dust of the earth shall awake, some to everlasting life, and some to shame and everlasting contempt" (Daniel 12.2).

4 "When Paul noticed that some were Sadducees and others were Pharisees, he called out in the council, 'Brothers, I am a Pharisee, a son of Pharisees. I am on trial concerning the hope of the
} 
Moreover, skepticism toward the idea was not confined to the Jewish community. The second century philosopher Celsus mocked Christian hope in bodily resurrection as "the hope of worms. For what sort of human soul would have any further desire for a body that had rotted?"5 Christians sensed such skepticism even earlier, as the Book of Acts reports Paul taking his message of new life in the risen Christ to Athens, where he met Greeks at the Areopagus who "scoffed" at "the resurrection of the dead." From Paul's accusatory question to the Corinthians, it is apparent that some Greeks there bore similar suspicions.

In their older accounts of the afterlife, both Jewish and Greek traditions described the possibility of a shadowy existence in Sheol or Hades, respectively, but the two traditions diverged when it came to more optimistic and glorious accounts of the afterlife that emerged closer to the first century C.E. While the rabbis, operating with a traditionally material anthropology ("You are dust and to dust you shall return," Gen 3.19), posited a resurrected flesh, some Greek philosophers in the Platonic tradition suggested that bodily life stood not as a vehicle toward glory but an impediment: not that in which but rather from which we are saved. Plato's ideal, for instance, involved the soul's immaterial contemplation of the form of the Good. ${ }^{7}$ But whether those in Corinth had in mind more traditional ideas of Hades, immaterial Platonic possibilities, or Aristotelian doubt about any afterlife at all, the Pharisees' notion of bodily resurrection was largely foreign to respectable Greek thought on the topic. ${ }^{8}$

resurrection of the dead.' When he said this, a dissension began between the Pharisees and the Sadducees, and the assembly was divided. (The Sadducees say that there is no resurrection, or angel, or spirit; but the Pharisees acknowledge all three.)" (Acts 23.6-8; see also Matt 22.23-33)

${ }^{5}$ Qtd in Origen, Against Celsus 5.14, trans. Henry Chadwick (Cambridge: Cambridge University, 1965), 274. See Brian E. Daley, "A Hope for Worms: Early Christian Hope," in Resurrection: Theological and Scientific Assessments, ed. Ted Peters et al, (Eerdmans: Grand Rapids, 2002), 13664 , at 138.

${ }^{6}$ Acts 17.23; cf.

${ }^{7}$ For a succinct overview of various Hellenistic (Platonic, Aristotelian, Neo-Platonic, Stoic, and other) theories of the soul and afterlife operative in the early Christian milieu, see Daley, "A Hope for Worms," 137-39.

${ }^{8}$ Cf. The reaction of the Athenians to Paul's message: "May we know what this new teaching is that you are presenting? It sounds rather strange to us" (Acts 17.39). Raymond Collins explains, "The idea of bodily resurrection is one that derives from a Jewish apocalyptic understanding. At best Hellenistic thinkers would have thought in terms of the immortality of the soul. Not so Paul and those Jews who espoused the notion of bodily resurrection. <...> Rabbis raised questions as to whether the bodies of those who are raised from the dead will be perfect bodies or the imperfect bodies of ordinary humans. $<\ldots>$ Speculation on questions such as these appear in b. Ketub. 11a; b. Sanh. 90b; y. Kil. 9:3; y. 
Paul's message in 1 Cor 15 thus stands as a sort of sales pitch to these suspicious Greeks. How, precisely, he designed such a pitch has been a matter of debate almost since he wrote it. James Ware has helpfully categorized these early Christian interpretative strategies into three camps. ${ }^{9}$ The first, consisting of dualist Christians who were later described broadly as "Gnostic," interpreted Paul in a more Platonic fashion. ${ }^{10}$ That is, grounding their reading in passages like "flesh and blood cannot inherit the kingdom of God, nor does the perishable inherit the imperishable" (1 Cor 15.50), these dualists took the situation in Corinth to be one of misunderstanding: Paul's message was not in fact one of bodily resurrection (like most other Pharisees held), but of new, immaterial life. It was a message of stark discontinuity between bodily life as we know it and the life of the spirit to come. ${ }^{11}$

For the second century bishop of Lyons, Irenaeus, this Gnostic interpretation grossly distorted Paul's intent. Likening the Scriptures to a beautiful mosaic of a king, Irenaeus suggests that the Gnostics had violently rearranged the individual stones of the mosaic to fashion a dog or a fox and then subsequently declared such a counterfeit image to be that of the king. ${ }^{12}$ The true Gospel message, Irenaeus counters, is not one of God rescuing us from a repugnant material creation, but rather God - the same God who both creates and redeems - bringing his material children to their properly intended maturity. ${ }^{13}$ That is, Irenaeus argues

Ketub. 12:3; Qoh Rab. 1:4; 2 Apoc. Bar. 49; and elsewhere" (Collins, First Corinthians, vol. 7 of Sacra Pagina, ed. Daniel Harrington (Collegeville, MN: Liturgical Press, 1999), 563). However, for examples of resuscitation and rejuvenation in Greek literary and mythological material, see Dag Øistein Endsjø, "Immortal Bodies, Before Christ: Bodily Continuity in Ancient Greece and 1 Corinthians," Journal for the Study of the New Testament 30.4 [2008]: 417-36.

9 James Ware, "Paul's Understanding of the Resurrection in 1 Cor 15:36-54," Journal of Biblical Literature 133.4 [2014]: 809-35, at 815-16.

10 The variety among such "Gnostic" groups has led some scholars to question the usefulness of the term itself. On this question, see Cyril O’Regan, "Historiographic Sophistications: Did Gnosticism Exist?” in Church Life Journal, 28 April 2020, https://churchlifejournal.nd.edu/articles/thehistoriography-of-gnosticism-and-the-demands-of-theory/

${ }^{11}$ For more on Gnostic views about bodily resurrection, including those found in the second century Epistle to Rheginos, see Daley, "Hope for Worms," 145-47.

${ }^{12}$ Against Heresies 1.8.1

${ }^{13}$ Irenaeus describes this maturation process reaching its culmination in and through Christ. "“'If, however, any one say, 'What then? Could not God have exhibited man as perfect from the beginning?' let him know that, inasmuch as God is indeed always the same and unbegotten as respects Himself, all things are possible to Him. But $<\ldots>$ as it certainly is in the power of a mother to give strong food to her infant [but she does not do so], as the child is not yet able to receive more substantial nourishment; so also it was possible for God Himself to have made man perfect from the first, but man could not receive this [perfection], being as yet an infant. And for this cause our Lord, in these 
that God saves through rather than from matter,${ }^{14}$ centering his claim on the Christian story of the incarnation (God taking on created flesh in order to redeem it) ${ }^{15}$ and the practice of the Eucharist (receiving Christ's body and blood to transform our own). ${ }^{16}$ For Irenaeus, resurrected life is the final stage of human development, which is bodily (though in different ways) through and through. It is thus a story in which Paul's themes of discontinuity in 1 Cor 15 are tempered by a strong, underlying story of continuity. (We will consider passages that support such continuity shortly.)

A third way between Irenaean and Gnostic dualist interpretations of Paul's writing on resurrection was suggested by Origen of Alexandria, the great third century biblical exegete. Origen agreed with Irenaeus that resurrected life was bodily, but he shared the dualist suspicion of our frail, fleshy bodies having much of a future after their disintegration.

last times, when He had summed up all things into Himself, came to us, not as He might have come, but as we were capable of beholding Him. He might easily have come to us in His immortal glory, but in that case we could never have endured the greatness of the glory; and therefore it was that He, who was the perfect bread of the Father, offered Himself to us as milk, [because we were] as infants. He did this when He appeared as man, that we, being nourished, as it were, from the breast of his flesh, and having, by such a course of milk-nourishment, become accustomed to eat and drink the Word of God, may be able also to contain in ourselves the Bread of immortality, which is the Spirit of the Father" (Against Heresies 4.38.1, in The Ante-Nicene Fathers [henceforth ANF] vol. 1, The Apostolic Fathers with Justin Martyr and Irenaeus, ed. Alexander Roberts and James Donaldson [Buffalo, NY: Christian Literature Publishing, 1885], 315-567, at 521).

${ }^{14}$ According to Matthew Steenberg, Irenaeus's magnum opus Against Heresies offers "a deliberate counter to the proliferation of anti-materialistic, dualistic views in the groups against which Irenaeus writes, not only through the reaffirmation of humanity's material nature, but also of God's continued use of the material order to effect human salvation" (Matthew C. Steenberg, Irenaeus on Creation The Cosmic Christ and the Saga of Redemption [Leiden: Brill, 2008], 118).

${ }^{15}$ Irenaeus explains that Christ "had Himself, therefore, flesh and blood, recapitulating in Himself not a certain other, but that original handiwork of the Father $\langle\ldots\rangle$. [T] he righteous flesh has reconciled that flesh $<\ldots>$ and brought it into friendship with God" (Against Heresies 5.14.2, in ANF 1:541).

${ }^{16}$ Citing Against Heresies 5.2.3, Caroline Walker Bynum explains, "Irenaeus thus suggests that the proof of our final incorruption lies in our eating of God. The very 'truth' of our flesh is 'increased and nourished' in the Eucharist. $<\ldots>$ We drink blood in the cup; blood can come only from flesh and veins; we know that our flesh is capable of surviving digestion exactly because we are able to digest the flesh of Christ. The fact that we are what we eat - that we become Christ by consuming Christ, but Christ can never be consumed - guarantees that our consumption by beasts or fire or by the gaping maw of the grave is not destruction. Death (rot, decomposition) can be a moment of fertility, which sprouts and flowers and gives birth to incorruption. Because eating God is a transcendent cannibalism that does not consume or destroy, we can be confident that the heretics who would spiritualize the flesh are wrong. Flesh, defined as that which changes, is capable of the change to changelessness" (Bynum, The Resurrection of the Body in Western Christianity, 200-1336 [New York: Columbia University Press, 1995], 39). Cf. Against Heresies 5.2.3. 
Accordingly, and with his own textual support from Paul (who contrasted "earthly" bodies with "heavenly" ones), ${ }^{17}$ Origen suggested that the souls of the deceased will be united not with their former, fleshy bodies but with new bodies composed of a "higher" and more refined material, ether. ${ }^{18}$

Origen's view was condemned some three centuries after his death at the Second Council of Constantinople (553 C.E.); mainstream Christian doctrine and even, eventually, secular biblical exegesis came to be dominated by the opinion that Ireaneus's reading - with its emphasis on continuity and resurrected flesh - was more faithful to Paul. ${ }^{19}$ Even so, Origen's position has staged a comeback in recent decades and contemporary scholarship is

17 "There are both heavenly bodies and earthly bodies, but the glory of the heavenly is one thing, and that of the earthly is another. There is one glory of the sun, and another glory of the moon, and another glory of the stars; indeed, star differs from star in glory. So it is with the resurrection of the dead" (1 Cor 15.40-42).

${ }^{18}$ According to Origen, "a body is controlled by nature, which puts something such as food into it from without, and as this food is eliminated, [it adds] further things, such as vegetable and animal products, in place of the other materials it had previously put there. Thus the body has not inaptly been called a river.

For strictly speaking, the first substratum (proton hypokeimenon) in our bodies is scarcely the same for two days, even though, despite the fluidity of the nature of a body, Paul's body, say, or Peter's, is always the same. <...> This is because the form (eidos) which identifies the body is the same, just as the features which characterize Peter's or Paul's bodies remain the same - characteristics like childhood scars, and such peculiarities as moles, and any others besides. This form, the bodily, which constitutes Peter and Paul, encloses the soul once more at the resurrection, changed for the better although surely not this extension which underlay it at the first. For as the form is the same from infancy until old age, even though the features appear to undergo considerable change, so we must suppose that, though its change for the better will be very great, our present form will be the same in the world to come" (from Origen's commentary on Psalm 1.5, qtd. in Daley, "Hope for Worms," 155-56). Bynum comments, "This fluctuating mass of matter cannot rise, [Origen] argues; it is not even the same from one day to the next. But, says, Origen, there is a body. . . body, as Origen understands it, changes in life; therefore it certainly changes after death" (Bynum, Resurrection, 65). Continuing, Origen elaborates, "And just as we would $\langle\ldots\rangle$ need to have gills and other endowment[s] of fish if it were necessary for us to live underwater in the sea, so those who are going to inherit [the] kingdom of heaven and be in superior places must have spiritual bodies. The previous form does not disappear, even if its transition to the more glorious [state] occurs, just as the form of Jesus, Moses and Elijah in the Transfiguration was not [a] different [one] than what it had been. Moreover $<\ldots>$ 'it is sown a psychic body, it is raised a spiritual body' (1 Cor 15.44). <..> [A]lthough the form is saved, we are going to put away nearly [every] earthly quality in the resurrection $<\ldots>$ [for] 'flesh and blood cannot inherit [the] kingdom . . ' (1 Cor 15.50). Similarly, for the saint there will indeed be [a body] preserved by him who once endured the flesh with form, but [there] will no longer [be] flesh; yet the very thing which was once being characterized in the flesh will be characterized in the spiritual body" (quoted in Bynum, Resurrection, 65-66, emphasis added).

${ }^{19}$ Ware, "Paul's Understanding of the Resurrection", 811. 
by no means settled on how Paul understood resurrection. And as James Ware has rightfully pointed out, the theological stakes surrounding the question are high: in the balance hangs fundamental implications for both Christian anthropology (what the human person is) and eschatology (the final hope in things to come). ${ }^{20}$

Our purpose here is not to evaluate the exegetical or theological merits of these diverse, competing interpretations of 1 Cor 15, but to explore the implications of one namely, the Irenaean camp - for the purposes of comparing Paul's solution to similar moves made by Aristotle. To reiterate, against both the Gnostic and Origenist readings of Paul, Irenaeus and the conciliar tradition insist that the resurrection involves the very material, fleshy bodies that we have now, transformed by the process as they may be. The subsequent treatment of Paul will operate in this vein.

\section{I.2. Paul's Case for Continuity and Discontinuity: Putting on Imperishability}

Paul's answer to his question "how can some of you say that there is no resurrection of the dead?" consists of two parts. The first part affirms that the dead are raised and involves several lines of argument, all of which are grounded in the faith of the community. ${ }^{21}$ Paul hammers home this first part of his argument with a straightforward syllogism: Christ's resurrection is an indispensable part of the Christian faith; however, if there's no resurrection of the dead at all, Christ's resurrection is impossible, and so, as he chides his dubious readers in Corinth, their faith is "in vain" and "futile" (vv. 14, 17). Indeed, he goes so far as to say

\footnotetext{
20 "This debate has extraordinarily important implications for Paul's thought. If, on the one hand, Paul envisioned resurrection to either a disembodied or ethereally embodied state, Paul conceived of human redemption as a liberation from the present body and earthly existence, in order to share in the life of the heavenly realms. If, on the other hand, Paul envisioned a resurrection of the flesh, Paul conceived of human redemption as the restoration of the present body and its liberation from death, in order to share in the life of a renewed created order. The latter is a hope for the redemption of this world and this body; the former is a hope that this body and this world will be transcended in a world above" (Ware, "Paul's Understanding of the Resurrection in 1 Cor 15:36-54", 816).

${ }^{21}$ Before even asking the question, Paul begins with a creed-like introduction which reminds the Corinthians of the Gospel message he delivered to them earlier: that Jesus died for their sins, was buried, and was raised on the third day (vv. 3-4). He underscores the latter point by highlighting a series of witnesses to whom the risen Christ appeared, including Cephas (the Aramaic name for Peter), James, the apostles, more than 500 others (some of whom have died in the meantime), and last of all, Paul himself. He concludes his litany of witnesses by reminding those in Corinth that it is through such testimony that they "have come to believe" (v. 11).
} 
that their forgiveness of sins is not simply tied to Jesus' death (v. 3) but also requires his resurrection (v. 17). The ultimate Christian hope is Christ, in whom "all will be made alive" (v. 22). Without the keystone of the risen Jesus, the gospel message falls apart. Belief in the resurrection of the dead is thus non-negotiable.

Paul introduces the second part of his argument with another question: "How are the dead raised? With what kind of body do they come?" (v. 35). Having told those in Corinth that they must believe in a Gospel with resurrection or no Gospel at all ("Let us eat and drink, for tomorrow we may die," v. 32), he now sets out to defend the plausibility of resurrection, lest his readers abandon the faith altogether. His argument turns on a central point: our frail bodies as we know them now stand in both continuity and discontinuity with their eventual resurrected status.

At least on an Irenaean reading of Paul, this tension cannot be collapsed in either direction. The dubious Corinthians seem to err on the side of pure continuity, dismissing the sudden reappearance of a body - the deterioration of which they are keenly aware - as implausible. Paul rebukes those tempted to such thinking, "Fool! < .. > as for what you sow, you do not sow the body that is to be" (vv. 36-37) and joyfully proclaims, "Listen, I will tell you a mystery! We will not all die, but we will all be changed" (v. 51). And Paul's arguably dualist remark that "flesh and blood cannot inherit the kingdom of God" (v. 50) can be read as rebuke of an understanding of the resurrected body (soma pneumatikon) which is excessively continuous with the body which we know now (soma psychikon, v. 44). Given his audience, correcting this overly continuous perspective receives the lion's share of Paul's attention.

Nonetheless, Paul's text resists being collapsed in the other direction as well. Against the Gnostic dualists (or even an Origenist moderate), some elements of Paul's story are difficult to parse in starkly discontinuous terms. It is not a story of the dead simply being exchanged for something else, but of the dead being raised (v. 52). His hope is not for a bodiless existence or even existence with an altogether different body: rather, in the end, "this perishable body puts on imperishability, and this mortal body puts on immortality" (v. 54). In sum, the good news is not simply that we, in our present bodily weakness and fragility, will be superseded or replaced, but that "we will be changed" (vv. 51, 52). ${ }^{22}$ Such a tension

\footnotetext{
${ }^{22}$ As Bynum puts it, "two points are clear. First, to Paul, the image of the seed is an image of radical transformation: the wheat that sprouts is different from the bare seed; and that bare seed itself, while
} 
can be observed also in the stories of the risen Christ's appearances contained in the New Testament gospels, which were written in the decades after Paul's letters. The Jesus in these stories is neither a resuscitated corpse nor an immaterial ghost: against the latter, he has "flesh and bones" and left an empty tomb, but against the former he comes and goes inexplicably and is hardly recognized by his closest companions. ${ }^{23}$

What should we make of such an early Christian claim of both continuity and discontinuity? Is it a problematic case of trying to have one's cake and eat it too, refusing a necessary choice and ultimately settling for a nonsensical position? We contend that such an evaluation misconstrues what Paul and like-minded early Christians meant when they described bodily resurrection as a "mystery." Indeed, Aristotle wrestled with a remarkably similar case of continuity and discontinuity when considering natural animal development. Importantly, both Aristotle and Paul insisted that continuity and discontinuity are not simply mutually repugnant opposites but that they can - indeed, must - hang together in an account

lying in the earth, undergoes decay. Second, the image asserts (perhaps, without any intention on the author's part) some kind of continuity, although it does not explicitly lodge identity in either a material or a formal principle. The sheaf of grain is not, in form, the same as the bare seed, nor is it clear that it is made of the same stuff. It acquires a new, a 'spiritual' body. But something accounts for identity. It is that which is sown that quickens. If we do not rise, Christian preaching is in vain, says Paul; something must guarantee that the subject of resurrection is 'us.' But 'flesh and blood cannot inherit the kingdom.' Heaven is not merely a continuation of earth. Thus, when Paul says 'the trumpet shall sound $\langle\ldots>$ and we shall be changed,' he means, with all the force of our everyday assumptions, both 'we' and 'changed'" (Bynum, The Resurrection of the Body, 6).

${ }^{23}$ Many historical critics rightly warn against reading the gospels as pure journalistic accounts of events objectively reported. Indeed, their genre is different than "biography" in the contemporary sense of that term - the gospels are stories about historical events infused with theological reflection and are told to bring the reader to faith (see John 20.31). Even so, attending to these stories can provide important information about the content of that faith, including how early Christians described resurrected existence.

Against a story of pure continuity (simple resuscitation of a corpse), the risen Jesus is not initially recognizable (Luke 24.16), even to his friends (John 20.14, 21.4), and his body does puzzling things like suddenly appearing in locked rooms (John 20.19) and vanishing instantaneously (Luke 24:31). But against a sort of pure discontinuity, his disciples $d o$ eventually recognize him (Luke 24.31, John 20.16, 21.7), he assures them that he has "flesh and bones" and is not "a ghost" (Luke 24.39), he cooks (John 21.9ff) and eats fish (Luke 24.43), and all four gospels report an empty tomb (Matt 28.6, Mark 16.6, Luke 24.3, John 20.2). On the whole, the gospels do not portray Jesus' resurrection as a mere resuscitation (as was the case with Lazarus in John 11.38-44 - note the way the author contrasts details like burial clothes in the accounts of Lazarus and Jesus, John 20.1-10); at the same time, the empty tomb, in particular, can and has been read as having implications for his corpse that challenge a Gnostic (immaterial) or Origenist (replacement material) account of resurrection. On an Irenaean account, the story is one of both continuity and discontinuity: numerically the same body but utterly transformed. 
of growth ordered toward a greater and more fundamental reality. Before seeing how Paul lays out his resolution, we will explain how the same mystery arises in Aristotle.

\section{Aristotle: the Puzzle of Animal Generation}

Aristotle's innovations in the science of biology were motivated by his own investigations into the complexities of animal life. It is well-known that he developed a taxonomy for classifying animals at more and less general levels of similarity, taking pains to consider all the differences between animals that might be relevant without oversimplifying the dizzying biological details. Aristotle's engagement with the generation of animals - the process of development from embryo to mature organism-is no less impressive in this respect. Here Aristotle deals with the dilemma of continuity and discontinuity that arises during natural animal development-a dilemma analogous, as we will see, to the one we have explored in Paul's letter regarding the shift between earthly and resurrected bodily life. Moreover, in so doing Aristotle argues, just as Paul did, against those who have chosen to embrace one horn of the dilemma at the expense of the other.

\section{II.1 Background: Aristotle on Animal Generation}

Aristotle denies pangenetic accounts of animal development on which, as H. de Ley puts it, "the development of the embryo is merely the enlargement and manifestation of structures already 'preformed' in the seed." 24 Such accounts were espoused by Democritus and Anaxagoras among others. Aristotle not only embraces but explores the discontinuity between different stages of animal generation in detail, devoting considerable attention to the order in which the different parts develop. In stark contrast to pangenetic views, he concludes in Generation of Animals (GA) that "the end [of animal development] is earlier than some parts and later than others" $\left(742^{b} 11-2\right)$. At the same time, however, Aristotle denies the Empedoclean view that the various parts of the animal and the developmental processes that yield each of them are distinct — indeed separable - existences that merely happen to occur

\footnotetext{
24 "Pangenesis versus Panspermia Democritean Notes on Aristotle's Generation of Animals", Hermes 108.2 (1980): $129-153$ at 130.
} 
contiguously in time and space. He concludes instead that these different processes are all stages in the unified and ongoing development of one single living body. ${ }^{25}$

Aristotle's disavowal of a purely continuous account of the generation of an animal body parallels Paul's disavowal of a purely continuous account of the resurrection of the body, i.e. one that sees the resurrected body merely as a resuscitated corpse. And Aristotle's disavowal of a purely discontinuous account of animal generation parallels Paul's disavowal of a purely discontinuous account of bodily resurrection, i.e. one that sees the resurrected life as immaterial (Gnostic) or with a different body altogether (Origenist). In the rest of this section we will establish Aristotle's seemingly dilemmatic commitment to both the continuity and the discontinuity of animal development by investigating his opposition to his predecessors who privileged one over (indeed, even at the expense of) the other.

\section{II.2. Aristotle vs. Empedocles and Anaxagoras: the Case for Continuity and Discontinuity}

Aristotle broadly criticized his predecessors in natural science for having a narrow engagement with natural phenomena, for imposing theories that sound compelling but fail to map onto a wide enough array of cases in nature. ${ }^{26}$ One such predecessor was Empedocles, who viewed animal development as a discontinuous series of stages. Indeed, as Aristotle points out in $G A 1.18$, Empedocles goes so far as to claim that individual parts of an animal can, not only in principle but indeed under the conditions present during the cosmic era Empedocles calls the "Reign of Love," develop by themselves independently of the other parts we usually see in that kind of animal - that is, individual developmental stages can occur in abstraction from the process of development associated with an animal taken as a

\footnotetext{
${ }^{25}$ As Allan Gotthelf and Andrea Falcon put it, "the formation and development of the embryo are to be conceived as a single, unified process controlled by a single causal power" ("One Long Argument'? The Unity of Aristotle's Generation of Animals", in Aristotle's Generation of Animals: A Critical Guide, ed. Andrea Falcon and David LeFebvre [Cambridge: Cambridge University Press, 2018], 15-34 at 27).

${ }^{26}$ Sean Kelsey, "Empty Words," in Theory and Practice in Aristotle's Natural Science, ed. David Ebrey (Cambridge: Cambridge University Press, 2015), 199-216. Kelsey discusses Aristotle's critique of predecessors such as Empedocles for succumbing to the risk "that over-emphasizes argumentation ( $\lambda$ óyol) at the expense of a broad, deep, and personal familiarity with the realities $(\pi \rho \alpha ́ \gamma \mu \alpha \tau \alpha) "(216)$.
} 
whole. During the "Reign of Love", Empedocles states, "'many heads sprang up without necks', and later on these isolated parts combined into animals" (722b20-21).

These passages show that Empedocles fully embraced the discontinuity involved in the process of animal generation, at the expense of any continuity whatsoever. Although an animal's parts happen to develop one after the other in a certain order and relationship, this broader context of animal generation taken as a whole is irrelevant to the nature and generation of each part taken singly. On an Empedoclean view of animal generation the shorter stages and the individual parts yielded by them are the independently intelligible phenomena, while the development of the animal taken as a whole is to be understood merely as a conglomeration of these shorter stages. For Empedocles, there is no ongoing unity of the body as a whole throughout the process of animal generation, but merely a contiguous series of separable parts.

Aristotle clearly disavows Empedocles's discontinuous account of animal generation: "Now that this is impossible is plain, for neither would the separate parts be able to survive without having any soul or life in them, nor if they were living things, so to say, could several of them combine so as to become one animal again" (722b22-24). But he goes further than affirming the mere impossibility of this view; he also decries it as "unintelligible" (aloga) (722b30). His point is not merely that Empedocles's far-fetched story could not possibly occur; it is the deeper point that it does not meet the criteria for counting as a genuine explanation. Why? First, he believes that the separate parts cannot survive without being connected together in the unified life of the animal; thus it is unreasonable to suppose that they could come into being separately and then be melded together. But moreover, as Aristotle goes on to explain, even if we overlook this difficulty and hypothesize that the parts could exist and survive separately, there would then be no reason to suppose they would ever come together as a unified creature - they would be analogous to separate animals. The fact that time and time again we do find them growing together in the unified life of a whole animal of a certain kind, then, is evidence that the separate parts of the animal, along with the separate stages of animal generation that give rise to each part, are not to be explained in discontinuous abstraction from the whole. In short, Aristotle discredits the intelligibility of the Empedoclean view precisely because it analyzes animal generation as a discontinuous process. 
Aristotle is equally opposed to an Anaxagorean pangenetic view of animal generation, according to which the apparent differentiation of an animal's parts occurs "because like is naturally carried to like" (740b14-15). Such a view would have it that within the sperma, the pre-existent reproductive fluid responsible for animal generation (Aristotle's "general name for semen and menstrual fluid," as Anthony Preus puts $\mathrm{it}^{27}$ ), the various parts of the animal are already actually present, needing only to be unmixed or separated out. Since Anaxagoras's view focuses on undifferentiated parts like flesh and bone (rather than on organs like heart or eye), Aristotle summarizes his view as the view that "none of the homogeneous parts come into being" (723a5-7). In GA 2.4 he discusses the implications of this view for animal generation thus:

But the parts are not differentiated, as some suppose, because like is naturally carried to like. Besides many other difficulties involved in this theory, it results from it that the homogeneous parts ought to come into being each one separate from the rest, as bones and sinews by themselves, and flesh by itself, if one should accept this cause. (740b12-19)

On the one hand, this view simply makes incorrect predictions: flesh, bone, and sinew come together during animal generation in a complex web of interaction right from their first appearance, not in three separate zones that later undergo mixing. Further, as he lays out in GA 1.18, "Nor can we say that it is increased later by a process of mixing, as wine when water is poured into it. For in that case each element would be itself at first while still unmixed, but the fact rather is that flesh and bone and each of the other parts is such later. And to say that some part of the sperma is sinew and bone is quite above us, as the saying is" (723a16-21). The point here is that parts like flesh, bone, and sinew manifestly arise later in the process of development, not from the start; affirming sinew and bone to be actually present in the originating sperma would thus have a purely theoretical basis, with no connection to the facts we observe on the ground.

But the trouble with the view goes deeper than the mere fact that it makes incorrect predictions, or at least predictions that are "quite above us" in the sense that they cannot be investigated via the facts on the ground but are doomed to remain purely theoretical. As he did with Empedocles, Aristotle goes deeper and critiques the intelligibility of this explanation:

27 "Science and Philosophy in Aristotle's Generation of Animals", Journal of the History of Biology 3.1 (1970): $1-52$ at 7. 
$[\mathrm{H}]$ ow will the sperma become greater by the addition of something else if that which is added remain unchanged? But if that which is added can change [metaballein], then why not say that the sperma from the very first is of such a kind that blood and flesh can be made out of it, instead of saying that it itself $i$ blood and flesh? (723a12-17)

Aristotle's trouble with the intelligibility of the Anaxagorean view, in short, lies with that view's implication that animal generation is merely a process in which already existing parts undergo growth, not a process whereby any new parts come into being. The problem is that the sperma could not even grow if that which was added to it in the process of growth were to simply remain what it was; the result of such an addition would be no more than a mixture of sperma with something else, not a genuine growth of sperma. Therefore, at the expense of making growth impossible, even a proponent of this view must maintain that what is added to sperma in the process of growth can change into sperma. But as long as this must be maintained, why not maintain straightaway that the sperma itself can undergo change? What is to be gained by having the sperma as an unchanging "middle man" in the process of development, when change must be introduced at the next stage anyway? In short, Aristotle's critique of the intelligibility of this explanation targets the fact that it analyzes animal generation in a purely continuous fashion, disallowing any genuine coming into being of parts that were not already present.

\section{Aristotle on Continuity and Discontinuity: Growing Toward a Solution}

But what positive view of animal generation opposes both the Empedoclean and the Anaxagorean views? How can we ensure that the requirement for continuity in the process as a whole does not conflict with the requirement that there is genuine coming into being of all the various parts, i.e. genuine discontinuity from stage to stage? In this section I will argue that Aristotle achieves this alternative by denying a premise shared by both Empedocles and Anaxagoras. Aristotle claims that scientific engagement into the process of animal generation must be careful not to mistake the temporal order, the order in which an animal develops, for the order that reveals and explains the being and nature of animals. As he puts the point:

[W] hen we are dealing with definite and ordered products of nature, we must not say that each is of a certain quality because it becomes so, rather that they become so and so because they are so and so, for the process of becoming attends upon being and is for the sake of being, not vice versa. (778b26) 


\section{III.1. Aristotle's Key Insight: Becoming for the Sake of Being}

What does Aristotle mean by his cryptic refrain that becoming is for the sake of being, not vice versa? 'Being' in this context is, for Aristotle, a generalized way of referring to the nature of a specific kind of animal taken as a whole, e.g. the way in which all the different parts of an elephant fit together, and the priority or dependency relationships that obtain between those parts, in the life activity characteristic of elephants. 'Coming to be' is a generalized way of referring to the developmental process for a certain kind of animal, e.g. the temporal order in which the parts of an elephant are each completed. The upshot of this refrain, then, is that priority in being cannot simply be read off the temporal order of priority we see in the developmental process; just because one part may come into being before another part does not mean that the earlier part is prior in being to the later part. Rather, we must understand the developmental order of the elephant's parts by reference to the relationships between those parts in the order of being. It is not the order of development, but rather the order of being, that is independently intelligible.

In the very first chapter of $P A$ he is at pains to emphasize that there is a connection between how he explains the parts of an animal and how he will explain the generation of an animal:

The fittest mode, then, of treatment is to say, a man has such and such parts, because the essence of man is such and such, and because they are necessary conditions of his existence, or, if we cannot quite say this then the next thing to it, namely, that it is either quite impossible for a man to exist without them, or, at any rate, that it is good that they should be there. And this follows: because man is such and such the process of his development is necessarily such as it is; and therefore this part is formed first, that next; and after a like fashion should we explain the generation of all other works of nature. (640a33-640b4; emphasis added)

This passage reveals that Aristotle's commitment to the priority of the order of being over the order of coming to be for an animal is founded on a commitment of his familiar from $O n$ the Soul 2.1: that, as we see in the first sentence of the above passage, a living thing's parts are dependent - both ontologically and explanatorily — on the essence of the whole living thing, since it is only in the context of the whole living thing that they can achieve their function. ${ }^{28}$ The result is that for Aristotle, the whole living being is both ontologically and

\footnotetext{
${ }^{28}$ Consider, for example, his well-known assertion that an eye without sight is an eye in name only
} (De Anima 2.1, 412b17-22). As James G. Lennox explains, "For Aristotle the idea of the whole 
explanatorily prior to its parts. And given that what it is to be a certain part of an animal can only be explained by reference to what it is to be the whole animal-i.e. given that the essence or nature of the whole is prior to the essence or nature of the part-it follows that individual stages of animal development, considered in abstraction from other stages, will lack full intelligibility in their own right. For to explain individual stages in abstraction from other stages would just be to explain the parts present during those stages in abstraction from the whole. Given Aristotle's commitment to the ontological and explanatory priority of the whole over the parts, then, it follows that the temporal order in which an animal's parts develop is not independently intelligible.

Empedocles and Anaxagoras may seem on the face of it to hold opposing views, but at a deeper level both agree in affirming, contrary to Aristotle's innovative claim, that the order of becoming is ontologically and explanatorily prior to that of the being or nature of the animal taken as a whole. For both assume that the explanation of earlier developmental stages cannot depend on the parts yet to be developed in later stages (and thus cannot depend on the process as a whole). Empedocles, as we have seen, argued that the developmental stages for each part of an animal are intelligible apart from the developmental process taken as a whole-indeed, he went so far as to take them to be ontologically separable from the whole animal (as evidenced during his "Reign of Love"). If Empedocles is right, the temporal order does reveal the order of being: just as the parts of the animal come to be independently from the whole in the temporal order, so the being of each part is separate from that of the whole. The fact that many parts come to be in temporal separation from the whole reveals a deeper ontological separability for each part-the parts must be prior to the whole. Ontological priority is to be read off temporal priority.

On Anaxagoras's view the temporal order likewise matches the order of being for the animal, but for a different reason: all the parts of the animal there ever will be are already present from the initial stage of development (in the sperma). There is never a mismatch between the order of temporality and the order of being, but this lack of mismatch is due to the complete denial of any genuine discontinuity in the temporal order. Whereas Empedocles admits genuine discontinuity in the order of temporal development (that some parts come to

organism as a functional unity is bedrock. $<\ldots>$ That the performance of its living activities requires distinguishable parts with their own specific functional capacities come second" ("An Aristotelian Philosophy of Biology: Form, Function, and Development", in Acta Philosophica 1:26 (2017): 3352 at 43$)$. 
be earlier and others later), and divides the order of being according to the divisions we see in the temporal order, Anaxagoras denies that the temporal order of development admits of any genuine division. It is simply the continuous growth of parts already there from the start. Anaxagoras thus allows for continuity in the order of being (contra Empedocles), but only because he likewise posits continuity in the temporal order of development. Although we cannot easily observe them until later, all the parts are there from the beginning to the end of the process - thus again, temporal priority is the window to ontological priority.

On both accounts, the temporal order reveals the way things are. What is temporally prior is ontologically prior, and thus independently intelligible-either because (for Empedocles) individual stages of development are independently intelligible, yielding a thoroughly discontinuous account of animal generation as a series of independent stages rather than as the growth of one body, or because (for Anaxagoras) everything present at the end of the process of development already was at the beginning, yielding a purely continuous understanding of animal generation. Aristotle's goal in claiming that the order of being cannot be read off the order of becoming is to embrace both genuine discontinuity and genuine continuity within the process of development. Contra Anaxagoras, different parts do develop at different stages, and contra Empedocles, development is not simply a hodgepodge of independent stages but the unified coming into being of a single animal body. Embracing both continuity and discontinuity in the developmental process is only genuinely dilemmatic if we assume that the temporal order reveals the ontological order.

\section{III.2. The Greater Reality: Aristotle's Teleological Basis for Animal Generation}

Aristotle is committed to the claim that just because a certain bodily part exists first temporally does not mean that that part is prior in being (i.e. ontologically prior) to the parts that come later. But how are we to understand the order of being, if not via the temporal order? What is the alternative? For Aristotle the order of being is mapped not by the distinction between being earlier or later in time, but rather by the teleological distinction between potentiality and actuality - what is potentially is posterior in being to what is actually, even if what is potentially may be found earlier in time than what is actually. Aristotle sometimes makes the point by claiming that what is in potentiality is for the sake of 
what is actually, just as we have seen him claim that becoming is for the sake of being. The relationship between potentiality and actuality is thus teleological.

In GA 2.4 Aristotle uses this insight to distinguish his view about sperma from the Anaxagorean pangenetic view, according to which, as we have seen, all the parts of the body are already embedded in the sperma from the start: "The real cause why each of them [the parts of the animal body] comes into being is that the residue of the female is potentially such as the animal is naturally, and all the parts are potentially present in it, but none actually" (740 14 -21). As Sophia Connell explains, "Employing the potentiality/actuality distinction, which he thinks his opponents failed to hit upon, Aristotle posits that semen [sperma] is potentially capable of being the parts of the body rather than actually having been them". ${ }^{29}$ This distinction between potentiality and actuality explains how sperma, though temporally prior to the developed animal body with its differentiated parts, is nonetheless posterior in being to the developed animal body. For sperma is to be defined in terms of the developed animal, as all potentialities are defined in terms of their actualities, not the reverse. Aristotle drives home this mismatch between the ontological and temporal orders in PA 2.1: "In order of time, then, the material and the generative process must necessarily be anterior; but in logical order the substance and form of each being precedes the material..." (646b1-3).

Further, the actuality of the animal-its being - is not achieved all at once, but gradually over the course of animal development:

So it is not easy to distinguish which of the parts are prior, those which are for the sake of another or that for the sake of which are the former. For the parts which cause the movement, being prior to the end in order of development, come in to cause confusion ... And yet it is in accordance with this method that we must inquire what comes into being after what; for the end is later than some parts and earlier than others [my emphasis]. (742b3-12)

The end or goal (telos) of development is the 'actuality' of an animal (in terms of which purely potential stages like the sperma are to be defined). It is neither already present at an early stage as Anaxagoras affirmed, nor not present until some momentous later stage. Nor is it divided into separable stages, so that whatever arises at each moment in time is

${ }^{29}$ Aristotle on Female Animals: A Study of the Generation of Animals (Cambridge: Cambridge University Press, 2016), 100. 
independent in being as Empedocles affirmed. ${ }^{30}$ Instead, for Aristotle the 'end' of animal development is achieved, part by part, over the process taken as a whole. Thus, animal generation is not a series of separable stages as Empedocles had it, but the unified development of the originating sperma into the actuality for which it was in potentiality: namely, the animal body with all its different parts. The stages which are not part of the 'end' depend on and are to be understood in terms of the 'end,' even if they appear in temporal separation from other stages; and each individual part that does make up the 'end' of the animal is dependent on that 'end' taken as a whole. Neither, of course, is development a purely continuous Anaxagorean unmixing of pre-existent parts; for different parts genuinely come to be at different stages in the process.

Since Allan Gotthelf's deeply influential article on Aristotle's teleology in 1976, the literature on this topic has largely focused on the extent to which the development of an animal is the result of capacities or potentialities possessed by the lower-level material elements (fire, earth, air, water) involved in the composition of that animal or whether it is also due to, as Gotthelf puts it, "an irreducible potential for an organism of that form." ${ }^{31}$ This question makes the relevance of teleology turn on whether there is or is not a full explanation at the level of the elements, or whether there are "gaps" in the elemental story for teleology to fill in. But Aristotle's disagreement with Empedocles and Anaxagoras reveals an important role for teleology that is independent of this issue: to allow him to embrace both the manifest discontinuity between individual stages of development and the continuity of the process taken as a whole.

\section{Paul and the Greeks: Growing Toward a Solution}

\footnotetext{
${ }^{30}$ For example, Aristotle claims that the heart arises first, as most essential to the life of the organism, and the liver after that (734a28-9). The eyes arise much later, but are still part of the end of development (744b10-11).

31 “Aristotle's Conception of Final Causality", Review of Metaphysics 30.2 (1976): 226-254 at 250. Rival conceptions of final causality still often define themselves by this same question about the relationship between teleological causation and the causal capacities of independently intelligible materials, though giving different answers to it. For example, Michael Bradie and Fred D. Miller ("Teleology and Natural Necessity in Aristotle", History of Philosophy Quarterly 1:2 [1984]: 133146) argue that teleological causation may be compatible with a full material account of generation at some material level other than that of Aristotle's four elements. Richard Sorabji argues that teleological causation may be compatible with a full material account of generation at the level of the four elements (Necessity, Cause, and Blame: Perspectives on Aristotle's Theory [London: Duckworth, 1980], 145-154).
} 
As we saw earlier, Paul's community at Corinth, respectable Greeks as they were, harbored significant suspicions about the notion of bodily resurrection that Paul brought from his own Jewish context. The Greeks were familiar with what happens to our weak, transient bodies upon death; for them, talk of the afterlife was comfortably couched in either mythological terms (e.g. shades in Hades) or Platonic philosophical terms (e.g. souls contemplating immaterial forms), neither of which involved the messy idea of resuscitated flesh.

Addressing such an audience, Paul offered a two-sided message of both continuity and discontinuity. On the one hand, and against any suspicions of a base, reanimated corpse, Paul insisted that the resurrection is not simply a continuation of earlier bodily life, a mere resuscitation of what was already previously there. Things will not remain as they are: "we will all be changed" (v. 51). On the other hand, at least on an Irenaean reading, Paul is not advocating utter rupture with the past, as would occur with a purely immaterial "resurrection" (e.g. the Gnostics) or discarding the body in favor of an upgraded, more refined replacement (e.g. Origen). Indeed, "we will all be changed," as "this perishable body puts on imperishability, and this mortal body puts on immortality" (v. 54). ${ }^{32}$ Salvation for Paul is not a dualist escape from or replacement of the material world we know, but a wondrous transformation of it.

We closed our earlier considerations of Paul with a question that Aristotle likewise wrestled with: how can such continuity and discontinuity go together? Paul's response that such continuous and discontinuous resurrected life is "a mystery!" (v. 51) might tempt one to think that his paradox is at root a contradiction that he simply will not (or cannot) address. However, other parts of Paul's letter indicate that this "mystery" is not a means of punting or burying the question. Rather, he uses this term to gesture toward a solution to the question, a solution that bears remarkable parallels with Aristotle's answer to the dilemma we just saw: a process of growth and development toward a greater reality that transcends the temporal order.

\footnotetext{
${ }^{32}$ Cf. Athanasius of Alexandria (d. 373 C.E.) who in exegeting 1 Cor 15 and "blessed Paul, through whom we all have surety of the resurrection", writes, "Like seeds cast into the earth, we do not perish in our dissolution, but like them shall rise again" (On the Incarnation 4.21, (Crestwood, NY: St. Vladimir's Seminary Press, 2003), 50).
} 


\section{IV.1. Paul's Analogy: The Body as a Seed}

After arguing that the dead are raised, Paul starts off his account of how the body is raised by chiding the dubious Corinthians for their narrow imaginations. "Fool!" he begins, "What you sow does not come to life unless it dies. And as for what you sow, you do not sow the body that is to be" (vv. 36-37). In what follows, Paul explains that "flesh" (sarx) and "body" (soma) are not homogeneous realities; rather, they occur in a dizzyingly diverse number of forms.

Not all flesh is alike, but there is one flesh for human beings, another for animals, another for birds, and another for fish. There are both heavenly bodies and earthly bodies, but the glory of the heavenly is one thing, and that of the earthly is another. There is one glory of the sun, and another glory of the moon, and another glory of the stars; indeed, star differs from star in glory. (vv. 39-41)

Bodily life encompasses an enormous array of possibilities, some of which are even "heavenly."

Paul's analogy of the seed presupposes and builds on this scope of possibilities. After all, it is not immediately apparent why the mere existence of other kinds of bodily life should concern the dubious Corinthian - sure, the sun may have a body which is heavenly, but her own is not! The work done by Paul's analogy of the seed is to link together one's present bodily life with other possibilities. Having chided the Corinthians for assuming that bodily life as they know it is the end of the story, he invites them to consider the possibility that it is actually just a beginning stage: "as for what you sow, you do not sow the body that is to be, but a bare seed, perhaps of wheat or of some other grain" (v. 37). Drawing on an eminently familiar natural example, the growth of a plant from a seed, Paul defends the plausibility of transformation into something else, something fuller and greater than the present reality. ${ }^{33}$

33 "In the argument of Hellenistic rhetoric metaphors are singularly important providing they are 'neither strange nor superficial,' says Aristotle (Art of Rhetoric 3.10.6). Aristotle went on to say that 'smart sayings' are derived from metaphor (Art of Rhetoric 3.11.1, 6). 'It becomes evident to him [the hearer],' says Aristotle, 'that he has learnt something, when the conclusion turns out contrary to his expectation, and the mind seems to say, "How true it is! but I missed it"' (Art of Rhetoric 3.11.6). To meet Jewish speculation as to the nature of the resurrected body for the benefit of a Hellenistic community, some of whose members denied the possibility of the resurrection of the dead, Paul uses analogies drawn from the world of everyday experience. These were neither strange nor superficial. The first set of analogies is agricultural (vv. 36-38), the second zoological (v. 39), the third astronomical (vv. 40-41). The analogies speak to the unspeakable (see 2:9)" (Collins, First Corinthians, 563). 
Indeed, an acorn placed into the ground does not produce simply another acorn but a magnificent oak tree. Analogously, Paul seems to say, our weak flesh placed into the ground does not produce a mere reanimated corpse but something far greater: a soma pneumatikon, a spiritual body marked by imperishability, glory, and power (vv. 42-43). The seed may indeed die, but it is not the seed with all its transient qualities that we should fixate upon: our attention should turn to the transformation arising out of it.

The process of the seed's growth reinforces and ties together Paul's central message about continuity and discontinuity. Let us consider for a moment Paul's explanation, "What you sow does not come to life unless it dies" (v. 36) a bit more closely. Reading this explanation in light of Paul's later explanation of what is "sown" and what "come[s] to life" (namely, "It is sown a physical body, it is raised a spiritual body," v. 44), we can specify the following: "What you sow (i.e. the physical body) does not come to life (i.e. the spiritual body) unless it dies." Such a statement affirms clear discontinuity: the physical body, which stands as the terminus a quo, dies. At the same time, Paul's statement implies an incredible continuity: in this process of growth, which is from the "seed's" perspective a death, the physical body becomes the spiritual body (the terminus ad quem). To use Paul's own words, precisely "what you sow" indeed "come[s] to life." In this familiar (though nonetheless mysterious) analogy of the seed growing toward a greater reality, Paul integrates his twin themes of continuity and discontinuity into a single, intelligible story of transformation.

\section{IV.2. The Greater Reality: Paul's Christological Basis for Resurrection}

We saw above that for Aristotle's account of an animal's development out of earlier material, the temporal order does not take priority. Rather, the actuality of the organism takes priority, and this is achieved in pieces throughout the temporal span of animal development. In other words, for Aristotle the temporal order cedes priority to the ontological order.

Paul makes an analogous move. Part of Paul's problem with the dubious Corinthians is that they get things backwards by assuming that the body to be should be understood in terms of the body that already is, rather than vice versa - just as Empedocles and Anaxagoras understand later stages of development in terms of what exists earlier in development. Accordingly, their vision of any resurrected body is constrained to readily familiar categories, 
and so it is no wonder that such a vision (perhaps something akin to reanimated zombies!) is something they hesitate to accept.

In his letter, Paul invites the Corinthians to turn their vision of things that are and things to be on its head. Paul admits that, temporally speaking, the "physical body" comes first: "it is not the spiritual that is first, but the physical, and then the spiritual" (v. 46). But in the same breath, he pleads with his readers not to stop at that first step. Just as one ought not to expect a giant acorn to emerge from the ground, but rather an oak tree, the Corinthians ought to understand this body not as a static norm but as a predecessor, a stage that leads to a greater reality, the "spiritual body". Paul, like Aristotle, appeals to an order of priority beyond the temporal order — one that does not prioritize the "physical" body.

Now admittedly, for as striking as the parallels between the two cases are, such philosophical language regarding "orders of priority" sits a bit uncomfortably within an exegesis of Paul, who was less concerned with lecturing on metaphysics and more with preaching his Gospel. However, there are resources within Paul's work that allow for us to make the case for an order of priority weightier than the temporal order, though articulated more specifically in Paul's own terms. Along with his implicit prioritization of the plant (e.g. the oak tree) over the seed (acorn) in 1 Cor 15, Paul's letters gesture toward what we might call a Christological order of priority that stands as an essential part of his account of resurrection. Paul's explicit appeal to this Christological priority make for an intriguing early Christian point of comparison with Aristotle, who likewise accounted for the "mystery" of continuity and discontinuity in development by situating the temporal order in subservience to a greater unfolding reality. Let us elaborate on what Paul has in mind with such a Christological priority.

Immediately after raising his analogy of the seed progressing into a wondrously transformed plant, Paul presents another specifically human case of termini a quo and ad quem, namely, the "first man, Adam" and "the last Adam," Jesus: "It is sown a physical body, it is raised a spiritual body. If there is a physical body, there is also a spiritual body. Thus it is written, 'The first man, Adam, became a living being'; the last Adam became a life-giving spirit" (vv. 44-45). Elaborating on his allusion to the creation story in which "the LORD God formed man from the dust of the ground, and breathed into his nostrils the breath of life; and the man became a living being" (Gen 2.7), Paul continues, "The first man was from the earth, a man of dust; the second man is from heaven" (v. 47). The two "Adams" present two 
possibilities for human life, the earlier and the later, the "earthly" and the "heavenly," the "physical" and the "spiritual".

Importantly, when Paul appeals to the "spiritual body" in which resurrected humans will live, he is not referring simply to a discrete, private individual reality. Rather, as he makes clear in this and other letters, Paul understands each of us to be caught up in a larger human corporate identity, grounded finally in Christ. "Just as we have borne the image of the man of dust, we will also bear the image of the man of heaven" (v. 49). ${ }^{34}$ Christ thus has an inescapably outsized place in Paul's thinking about the resurrection. Not only is Jesus a key example of resurrected life, a "first fruits" (v. 20ff) who gives us a sneak preview of things to come, ${ }^{35}$ but he encompasses all who will live in resurrected bodies. Indeed, as Paul already indicated earlier in his argument, all may "die in Adam," but "all will be made alive in Christ" (v. 22).

Paul's vision of all being alive "in" Christ hearkens back to a theme he raises at multiple points earlier in the letter. Addressing factions and rivalries in the church community at Corinth, he urged his readers to recall that "you are the body of Christ and individually members of it" (12.27). Indeed, "just as the body is one and has many members, and all the

\footnotetext{
${ }^{34}$ See Paul's later letter to the Romans where he makes a very similar move: "Therefore, just as sin came into the world through one man, and death came through sin, and so death spread to all because all have sinned - sin was indeed in the world before the law, but sin is not reckoned when there is no law. Yet death exercised dominion from Adam to Moses, even over those whose sins were not like the transgression of Adam, who is a type of the one who was to come. But the free gift is not like the trespass. For if the many died through the one man's trespass, much more surely have the grace of God and the free gift in the grace of the one man, Jesus Christ, abounded for the many. And the free gift is not like the effect of the one man's sin. For the judgement following one trespass brought condemnation, but the free gift following many trespasses brings justification. If, because of the one man's trespass, death exercised dominion through that one, much more surely will those who receive the abundance of grace and the free gift of righteousness exercise dominion in life through the one man, Jesus Christ. Therefore just as one man's trespass led to condemnation for all, so one man's act of righteousness leads to justification and life for all. For just as by the one man's disobedience the many were made sinners, so by the one man's obedience the many will be made righteous. But law came in, with the result that the trespass multiplied; but where sin increased, grace abounded all the more, so that, just as sin exercised dominion in death, so grace might also exercise dominion through justification leading to eternal life through Jesus Christ our Lord" (5.12-21).

${ }^{35}$ Collins explains Paul's usage of "first fruits" imagery: First fruits are, "literally, the first portion of an agricultural harvest, the thing that precedes the rest of the harvest. As such it is a harbinger of things to come. The notion implies not only a temporal sequence but also some sort of relationship between the firstfruits and the later harvest: the harvest of firstfruits serves almost as a guarantee of the later harvest(s). It suggests, but does not actually prove, that a later harvest will take place" (Collins, First Corinthians, 547-48).
} 
members of the body, though many, are one body, so it is with Christ. For in the one Spirit we were all baptized into one body" (12.12-13). ${ }^{36}$ And earlier in the letter, exhorting the Corinthians to maintain bodily purity, he explicitly links this theme of incorporation with resurrection: "and God raised the Lord and will also raise us by his power. Do you not know that your bodies are members of Christ?" (6.14-15).

Any consideration of Pauline notions of resurrection needs to take this language very seriously. As the great liberation theologian Gustavo Gutiérrez has pointed out, Paul "use[s] the word body in a supra-individual perspective. Body is a factor in solidarity, and the body of Christ is the entire Christian community". ${ }^{37}$ Gutiérrez continues, "Readers often regard this theology of the church as simply a beautiful metaphor. However, we must, shocking though this idea may be, see through to the realism that characterizes the Pauline approach. He is speaking of the real body of Christ, which he looks upon as an extension of the incarnation". ${ }^{38}$ On such an outlook, Christians ought to understand their bodies not through the lens of the present temporal order or even exclusively individually as their own, but as incorporated into the glorified body of the risen Jesus.

Such an outlook helps to make sense of why Paul began his argument that the body is resurrected with a discussion of Jesus. On one level, his exhortation stands as a syllogistic argument: unless, generally, there is some resurrection of the body, you cannot have the specific resurrection of Jesus, which is a non-negotiable of the faith. On a second level, though, by considering Paul's theology of "membership" and incorporation into Christ, we begin to see why Jesus' resurrection stands as a non-negotiable of the faith. It is a sine qua non for any human resurrection, since all who will be raised "will be made alive in Christ" (v. 22), as members of his body. The entirety of Paul's soteriological hope is constructed upon the person of Jesus, who as the "last Adam" sums up how humanity will one day live and indeed is already beginning to live - anew.

There is indeed some temporal element to Paul's theory of the "first man, Adam" and the "last Adam," but the final word belongs to a reality greater than the temporal one. The

\footnotetext{
${ }^{36}$ See also Rom 12.5, where Paul writes, "we, who are many, are one body in Christ, and individually we are members one of another."

${ }^{37}$ Gustavo Gutiérrez, We Drink from Our Own Wells: The Spiritual Journey of a People (Maryknoll, NY: Orbis, 1984), 68.

${ }^{38}$ Gutiérrez, We Drink from Our Own Wells, 69.
} 
first Adam may have temporal priority but new life is found in the last one. But, just as Aristotle's notion of the actuality of the body is not to be relegated simply to the temporal end of animal development, so Christ's import does not lie simply in coming at the "end," temporally understood, for life has continued for two decades between Jesus' death and Paul's letter here, with Christ's disciples living and even dying in the meantime (v. 6). Nonetheless, their own hope was bound up with the fate of this man who came before them and who has inaugurated a new, risen life. In both his analogy of the seed and his discussion of Jesus and the resurrection, Paul points beyond a sort of temporal order for thinking about the problem. In the end, his hope and vision for the resurrection is grounded in a Christological order.

By insisting on both continuity and discontinuity in his letter to the dubious Corinthians, Paul is not settling for incoherency and contradiction. After all, it seems perfectly coherent to recognize that a seed in some ways is and in others is not the same as the plant that follows. Rather, Paul's letter is a plea to those who are familiar only with the "acorn" to widen their worldview to account for the "oak tree" that it has yet to become. And just as the oak tree teleologically grounds the best understanding of the acorn which precedes it, so the body of the risen Christ, with all its individual members, anchors Paul's hope in resurrected human life to come.

\section{Conclusion}

Presented with questions about bodily change, both Aristotle and Paul faced a seeming dilemma: should they emphasize the body's identity through the process of transformation, at the risk of undermining genuine change? For Paul, such a route was a nonstarter for his church in Corinth, who knew what happened to bodies placed into the ground and who had no time for tales of their reanimation. For Aristotle, this same emphasis on identity yielded a theory like Anaxagoras's, according to which animal development is reduced to the manifestation of parts that were already there (even if unobserved) in the first place - and such a theory fails to be animal development in much of a meaningful sense at all.

On the other hand, should they instead opt for bodily discontinuity, at the risk of compromising its identity through the process? Such an option, appealing though it may be 
to dualistic Gnostic sensibilities, ran counter to Paul's hopeful message that precisely what is sown in death is raised to new life, the message that we (rather than others) will be changed. Likewise, stark discontinuity in animal generation gravitated toward an Empedoclean theory in which the various parts and stages of development are not only independently intelligible, but even under certain circumstances independently existing. Just as Paul resisted severing resurrected life from his hope for the present world, Aristotle resisted theories which severed the stages of animal development from each other, on which "heads sprang up without necks".

Ultimately, each refused this dilemma as a false one rooted in an outlook which unnecessarily privileges temporal priority. Anaxagoras, Empedocles, the dubious Corinthians, and even the Gnostics all granted a normativity to earlier stages of bodily development that controlled their visions of later ones, later stages of growth which became construed as posterior not only temporally, but explanatorily and ontologically as well.

In refusing to pick one horn of the dilemma, Paul and Aristotle each invite their audiences to integrate both continuity and discontinuity into a new conceptual framework which privileges not temporal priority but the whole toward which earlier stages, in all their potency, develop. Aristotle's teleological emphasis on the actuality of the whole organism in order to understand earlier stages parallels Paul's pleas to construe the seed in terms of the plant to come, the "man of dust" in terms of the "man of heaven," and ultimately each individual human life as part of a greater integrative whole, the body of Christ.

Their proclamations of a new conceptual framework for understanding bodily development are announcements of "mystery." Importantly, mystery ought not to be taken as incoherence, contradiction, or even just an absence of knowledge. Rather, mystery refers to the rich implications contained within the things that we do know but which have yet to be fully appreciated and explored. Just as Heraclitus announced the presence of "divinities" in his kitchen, Aristotle and Paul invite their readers to consider mundane parts of their world - whether sperma or a failing body - as filled with wondrous potential, as sites that reveal a grander order if only we take them as pathways toward a humbling actuality rather than as normative ends in themselves. 


\author{
Anne Siebels Peterson \\ Brandon R. Peterson \\ University of Utah
}

\title{
Bibliography
}

Aristotle. Parts of Animals. Ogle, W. trans. The Complete Works of Aristotle, 2 vols., Barnes, J. ed. (Princeton, NJ: Princeton University Press, 1984).

Aristotle, De Anima. Smith, J.A. trans. The Complete Works of Aristotle, 2 vols., Barnes, J. ed. (Princeton, NJ: Princeton University Press, 1984).

Athanasius of Alexandria. On the Incarnation (Crestwood, NY: St. Vladimir's Seminary Press, 2003.

Bradie, Michael and Miller, Fred D. "Teleology and Natural Necessity in Aristotle," History of Philosophy Quarterly 1:2 (1984): 133-146.

Bynum, Caroline Walker. The Resurrection of the Body in Western Christianity, 200-1336 (New York: Columbia University Press, 1995).

Collins, Raymond. First Corinthians, vol. 7 of Sacra Pagina, Harrington, D. ed. (Collegeville, MN: Liturgical Press, 1999).

Connell, Sophia. Aristotle on Female Animals: A Study of the Generation of Animals (Cambridge: Cambridge University Press, 2016).

Coogan, Michael D. (ed.), The New Oxford Annotated Bible: New Revised Standard Version with the Apocrypha, $4^{\text {th }}$ edition (New York: Oxford University Press, 2010).

Daley, Brian E. “A Hope for Worms: Early Christian Hope," in Resurrection: Theological and Scientific Assessments, Peters, T. et al ed. (Eerdmans: Grand Rapids, 2002).

De Ley, Herbert. "Pangenesis versus Panspermia Democritean Notes on Aristotle's Generation of Animals," Hermes 108.2 (1980): 129-153.

Endsjø, Dag Øistein. "Immortal Bodies, Before Christ: Bodily Continuity in Ancient Greece and 1 Corinthians," Journal for the Study of the New Testament 30.4 [2008]: 417-36.

Gotthelf, Allan. “Aristotle's Conception of Final Causality," Review of Metaphysics 30.2 (1976): 226-254.

Gotthelf, Allan and Falcon, Andrea. “'One Long Argument'? The Unity of Aristotle's Generation of Animals", in Aristotle's Generation of Animals: A Critical Guide. Falcon, A and LeFebvre, D. eds. (Cambridge: Cambridge University Press, 2018), 15-34

Gutiérrez, Gustavo. We Drink from Our Own Wells: The Spiritual Journey of a People. O'Connell, Matthew J. trans. (Maryknoll, NY: Orbris, 1984). 
Irenaeus of Lyons. Against Heresies, in The Ante-Nicene Fathers, vol. 1, The Apostolic Fathers with Justin Martyr and Irenaeus, Roberts, A. and Donaldson, J. eds. (Buffalo, NY: Christian Literature Publishing, 1885), 315-567.

Kelsey, Sean. "Empty Words," Theory and Practice in Aristotle's Natural Science, Ebrey, D. ed (Cambridge: Cambridge University Press, 2015), 199-216.

Lennox, James G. "An Aristotelian Philosophy of Biology: Form, Function, and Development," Acta Philosophica 1:26 (2017): 33-52.

O’Regan, Cyril. "Historiographic Sophistications: Did Gnosticism Exist?” Church Life Journal, 28 April 2020, https://churchlifejournal.nd.edu/articles/the-historiography-of-gnosticism-and-thedemands-of-theory/

Origen. Against Celsus. Chadwick, H. trans. (Cambridge: Cambridge University, 1965).

Preus, Anthony. "Science and Philosophy in Aristotle's Generation of Animals," Journal of the History of Biology 3.1 (1970): 1-52.

Sorabji, Richard. Necessity, Cause, and Blame: Perspectives on Aristotle's Theory (London:

Duckworth, 1980).

Steenberg, Matthew C. Irenaeus on Creation - The Cosmic Christ and the Saga of Redemption (Leiden: Brill, 2008).

Ware, James. "Paul's Understanding of the Resurrection in 1 Cor 15:36-54," Journal of Biblical Literature 133.4 (2014): 809-35. 